\title{
LUT
}

University

Interplay Between Economics and Environment: Determinants of Sustainable Solutions

Rantala Tero, Saunila Minna, Ukko Juhani, Havukainen Jouni

This is a Author's accepted manuscript (AAM) version of a publication

published by Palgrave Macmillan, Cham

in Renewable Energy

DOI: $10.1007 / 978-3-030-14207-0 \_2$

Copyright of the original publication: (c) The Author(s) 2019

Please cite the publication as follows:

Rantala T., Saunila M., Ukko J., Havukainen J. (2019) Interplay Between Economics and Environment: Determinants of Sustainable Solutions. In: Kurochkin D., Shabliy E., Shittu E. (eds) Renewable Energy. Palgrave Macmillan, Cham

This is a parallel published version of an original publication. This version can differ from the original published article. 


\section{Interplay between economics and environment: determinants of sustainable solutions}

\section{Introduction}

The debate on sustainable development has long focused on the determinants promoting sustainable development. Some scholars have discussed environmental determinants, such as energy savings, pollution prevention, waste recycling, hygienic factors, land occupation, green product design, corporate environmental management, and ease of material handling (Chen et al., 2006, Pretty et al., 2011; Delai and Takahashi, 2011; Galdeano-Gómez et al., 2013). Others have investigated the social aspects of sustainability, such as social recognition, human capital development, job creation, and health and safety issues (Choi and $\mathrm{Ng}, 2011$; Delai and Takahashi, 2011Galdeano-Gómez et al., 2013; Khan et al., 2016). The economic aspects of sustainable development have also been heavily discussed, and scholars have suggested that sustainable development is driven by cost savings (Horbach et al., 2012; Horbach et al., 2013; Del Río et al., 2015; Hojnik \& Ruzzier, 2016) and increased revenue from new business opportunities (Delai \& Takahashi, 2011; Mamede \& Gomez, 2014; Schaltegger et al., 2016). These sustainable development studies with quite narrow viewpoints have yielded conflicting results and an unclear picture of what is being developed. The development target should be clearly defined to understand the determinants of the development.

The main focus of this study is to help fill these research gaps by exploring the determinants of the adoption of sustainable solutions in the horse industry. According to Liljenstolpe (2009), the number of horses has steadily increased in Europe, especially in urban areas, in the last 20 years. This situation constitutes some environmental burdens and challenges, one of which is related to horse manure production. Currently, little of the manure produced in urban areas can be used as fertilizer due to the small number of fields, creating challenges, operational harms, and costs to horse industry operators as they search for more sustainable solutions to manure handling. Therefore, to support the sustainable development of horse industry operators, the problems related to manure handling need to be solved. For example, the produced manure could be utilized in energy production or land use. The study was conducted in Finland, where currently only a fraction of the potential of horse manure is utilized and the horse industry continuously requires new sustainable solutions to support its development and manure utilization. New solutions for manure utilization can be investigated from four angles: new technology, services utilization, technology investment, and new business related to horse manure use. The definitions and differences of these solutions are discussed in more detail in the literature section.

In this investigation, the possible determinants of the adoption of the desired sustainable solutions are related to sustainability and operations. Sustainability determinants refer to those presented in the first paragraph (nutrient cycling, social recognition, job creation, health and safety, human capital development, cost reduction, and new business) while operational 
determinants consist of perceived harms, perceived cost harms, and actual costs of manure handling. Perceived harms arise as manure handling requires work time, which takes away from more productive work, such as teaching horseback riding and training horses. Perceived costs also derive from this situation as manure handling can be seen as a burden, which should be eliminated with the least cost possible. The actual costs of manure handling can vary greatly depending on the technology level, selected solutions, and size of the horse industry operation. Operational, as well as sustainability, determinants are considered to provide a more comprehensive understanding of the drivers that determine the desired solutions in the studied business environment.

The empirical results of the study were collected through a survey of 139 Finnish horse industry operators. The study contributes to research by presenting operational and sustainability determinants that affect the adoption and utilization of sustainable solutions. Although the results are gathered from Finland, we believe that the results can be useful in other countries, as national differences, such as in the horse industry, have become less important in Europe (e.g., Liljenstolpe, 2009). The results of the study can be interesting to horse industry operators in other countries worldwide, other agriculture industry operators, technology and service providers, policymakers, and governmental officers.

\section{Sustainable solutions}

One way to promote sustainable development in various industries is to create novel technologies, services, and business models. Technological solutions play important roles in solving sustainability challenges related to, for example, energy consumption and nutrient recycling (Long et al., 2016). Furthermore, in agriculture-related industries, climate change will affect crop distribution and production, increasing the risks associated with farming (Scherr et al., 2012). Consequently, in the coming decades, global food systems will come under growing pressure, and agriculture-related industries will face the challenge to provide food security to growing populations without enjoying ecosystem and environmental security (Calabi-Floody et al., 2018).

In addition to solving such environmental sustainability challenges, according to Anadon et al. (2015) and Shrivastava et al. (2016), novel technologies can make significant contributions to societal improvements, such as human well-being and economic growth. At the firm level, technology-related sustainable solutions usually arise from the utilization and adoption of technological solutions and products developed to improve firms' businesses and solve sustainability challenges. For example, by adopting climate-smart agricultural innovations (Scherr et al., 2012) at the firm and farm levels, operators in agriculture-related industries can achieve sustainable outcomes in nutrient recycling and field productivity while reducing the risk of climate change (Long et al., 2016). 
In addition to firms' internal motivation, external factors, such as governmental regulations and increased customer awareness, motivate firms to adopt sustainable solutions (Hojnik \& Ruzzier, 2016). In manufacturing industries, technology plays an important role in sustainable development by enabling improvements to manufacturing processes that reduce energy consumption and required materials (Yang et al., 2016). It, therefore, is necessary to use modern, sustainable technologies in agriculture-related industries to decrease the negative environmental impacts from chemical fertilization and inadequate disposal and reuse of agricultural waste (Calabi-Floody et al., 2018). While societal and external pressures and regulations push firms toward sustainable solutions and technologies, internal reasons and motivations also drive firms to adopt sustainable technologies. Among others, economic reasons, such as cost savings and increased revenue, are seen as drivers of firms' adopting sustainable technologies.

In addition to technology-related sustainable solutions, policymakers, academics, and practitioners have shown growing interest in a broader, holistic perspective on service innovation as a new, promising transcendent business logic fostering sustainability (Enquist et al., 2015; Calabrese et al., 2018). The service sector and sustainable services are increasingly components of firms' businesses and operations, including the agricultural industries (cf. Martin et al., 2016). The adoption of new sustainable services and strategies is viewed as an engine for the renewal of individual firms and entire industries and as a catalyst for business development (Snyder et al., 2016). Recent sustainability trends look more deeply at the development of services, in addition to new products and production processes (Laperche \& Picard, 2013). Moreover, the negative environmental effects of firms' operations can be reduced by increasing services in business environments and supply chains and dematerializing operations (Laperche \& Picard, 2013). Agricultural services have also been presented as a significant measure for promoting the development of modern agriculture and improving its output efficiency (Gao et al., 2018). Consequently, many industrialized countries, with government support, have established agriculture-related service systems with varied forms of services, such as comprehensive service contents, diversified service subjects, and coordinated, efficient operations (Gao et al., 2018). Service delivery and utilization are also considered to be part of firms' eco-design strategies to mitigate their operations' negative environmental effects by providing sustainable services rather than tangible products (Geum and Park, 2011; Laperche and Picard, 2013). Moreover, sustainable services open possibilities for firms to reduce operational harms and operational costs, increase revenue, and promote their brands (Furrer, 2010). In such result-oriented services, firms sell and seek capabilities and results instead of technological products. For example, a service with one operator or service provider responsible for all the costs of delivering results motivates optimal energy and materials use (Laperche \& Picard, 2013).

Despite the significant potential of new technological and service-related solutions, they have difficulties succeeding alone in the market (Chesbrough, 2010; Yang et al., 2016; Wamsler and Brink, 2018). To develop innovative business models to support circular economy goals and 
sustainable business development in general, it is important to consider that sustainability goals are not usually achieved by adopting only sustainable technologies or services but by also paying attention to business models (Yang et al., 2016; (Lüdeke-Freund and Dembek, 2017; Diaz Lopez et al., 2018). Although research on business models and business model innovation in general is mature, business model innovations for the circular economy and energy and resource efficiency seem to be less studied (Lüdeke-Freund and Dembek, 2017; Diaz Lopez et al., 2018). Business model strategies are not necessarily related to new technologies or services but are new ways of creating and delivering value to stakeholders (Björkdahl and Holmén, 2013; Yang et al., 2016). A sustainable business model "creates competitive advantage through superior customer value and contributes to the sustainable development of the company and society" (Lüdeke-Freund, 2010). Furthermore, business model innovations with social elements can support and increase customer interactions and improve unsustainable consumption behavior (Sousa-Zomer \& Cauchick Miguel, 2016).

\section{Determinants of sustainability}

\subsection{Determinants of sustainability in the horse industry}

Horses have a long tradition in Finnish society, but the agricultural revolution has made horses be used for recreation and leisure and no longer for labor. Currently, the main use of horses in Finland is associated with the horse racing sport. Nevertheless, many other activities require the use of horses, such as horseback riding, eco-tourism, and various forms of horse activities. Firms in the horse industry have struggled with their profitability for a long time. Increased costs and environmental regulations have brought them challenges, and therefore new solutions are needed to increase the profitability and business potential of these firms. A number of different options can be used to integrate sustainable solutions to the existing core business of firms. For example, wastes can be utilized as a material or as energy. The different utilization options can support, for example, the renewable energy production targets and the objectives of circular economy, such as nutrient recycling. Therefore, firms in the horse industry can employ a variety of solutions to build a new business, create jobs, improve energy selfsufficiency, and reduce greenhouse gas emissions. The horse industry offers a productive setting to study sustainable solutions and their determinants.

Sustainable horse manure handling is a relevant issue in the horse industry due to the associated costs and labor demand. Solutions can be found in four areas: new technology exploitation, services use, technology investment, and new business related to horse manure utilization. Exploitation of technology could involve transporting manure for local or central utilization and paying a gate fee to, for example, to a community-owned biogas plant or a neighbor for co-utilization without participating in the investment. This would require more involvement in manure handling than exploiting services in which the provider transports and treats the manure while providing the new bedding. Even more involvement is required when investing in technology for exclusive use, such as drum-composting devices. Starting a new business for 
horse manure utilization, such as centralized treatment of horse manure, demands taking an active role in transforming horse manure into products, such as organic fertilizers. This could mean starting a cooperative as a solution for a larger stakeholder group, such as centralized biogas production or horse manure combustion in a district heating plant.

The development of manure handling solutions from these four perspectives involves sustainability determinants. Hygienic factors, the wellbeing of stable personnel and horses, and the ease of manure management determine the actions by a stable. Bedding is selected to provide high absorption capacity, be safe for horses to walk on, and ensure good air quality in the stable. The stable machinery allows for easy cleaning and spreading new bedding. In the long term, social recognition, recycling of manure nutrients on arable land, and commitment to environmental causes are becoming important determinants of the development of manure utilization. Good cooperation with neighbors requires socially acceptable manure management, while applying manure on arable land enhances nutrient recycling. Eventually, increased revenue, job creation, and new business development can become determining motivations for finding sustainable solutions to manure handling. Prosperous agricultural regions require innovation to create new jobs and business opportunities to which the horse industry can contribute.

While sustainability determinants guide the development of horse manure handling, they are also affected by the operational determinants of perceived harms, perceived cost harms, and actual costs. Perceived harms arise as manure handling requires work time, which takes away from more productive work, such as teaching horseback riding and training horses. Perceived costs also derive from this situation as manure handling can be seen as a burden, which should be eliminated with the least cost possible. The actual costs of manure handling can vary greatly depending on the technology level, selected solutions, and size of the horse industry operation.

Among sustainability determinants, economic benefits are among the most important drivers of sustainable solutions and technologies. For example, sustainable solutions enabling the use of lesser raw materials are easily justified from the economic perspective as operational costs are reduced. The benefits for the company image are also important, and some sustainable solution investments can be justified by the positive effect on the company image. Ecolabelling is used to convey the information of these measures on the consumers in a more or less standardized format. McKinsey's global survey on the business of sustainability (Bonini and Görner 2011) summarizes that companies view the effects on reputation, operational and growth benefits from reduced costs, and new markets and products as the expected benefits from sustainability. The selection of a sustainable solution is increasing because of the increased stakeholder awareness. Stakeholders are increasingly demanding information on the life cycle effects of the products and services rendered. In a highly competitive business environment, sustainable solutions can also provide strategic advancement, for example, by increasing energy efficiency and reducing resource use. The main aim is cost reduction, without which the relocation of a company to country with reduced costs is needed (Radulescu, 2017). 
To establish and integrate sustainable solutions and to achieve the long-term social and environmental sustainability of enterprises, sustainable business models with a triple bottom line approach are needed. The sustainable business model archetypes proposed by Bocken et al. (2014) are as follows: maximize material and energy efficiency, create value from waste, substitute with renewables and natural processes, deliver functionality rather than ownership, adopt a stewardship role, encourage sufficiency, re-purpose the business for the society/environment, and develop scale-up solutions. These archetypes can partially including the four-step "natural capitalism" agenda proposed by Lovins et al. (1999; 2007): increased productivity of natural resources, imitation of biological production models, changing of business models, and reinvestment in natural capital..

\subsection{Summary}

As discussed, today's horse industry faces a need for sustainable solutions (technologies, services, and business models) to secure its survival. As horses increasingly move closer to urban areas, away from traditional farming areas, environmental and sustainability challenges emerge. This situation makes industry operators potential candidates for the adoption of sustainable solutions. The next section explores how determinants related to sustainability and operations influence horse industry operators' adoption of sustainable solutions. Sustainability determinants affect operators' valuation of sustainability aspects, such as nutrient cycling, waste management, hygienic factors, energy consumption, social recognition, ease of material handling, and commitment to environmental causes. Operational determinants reflect the significance of perceived operational harms, perceived cost harms, and actual costs of manure handling.

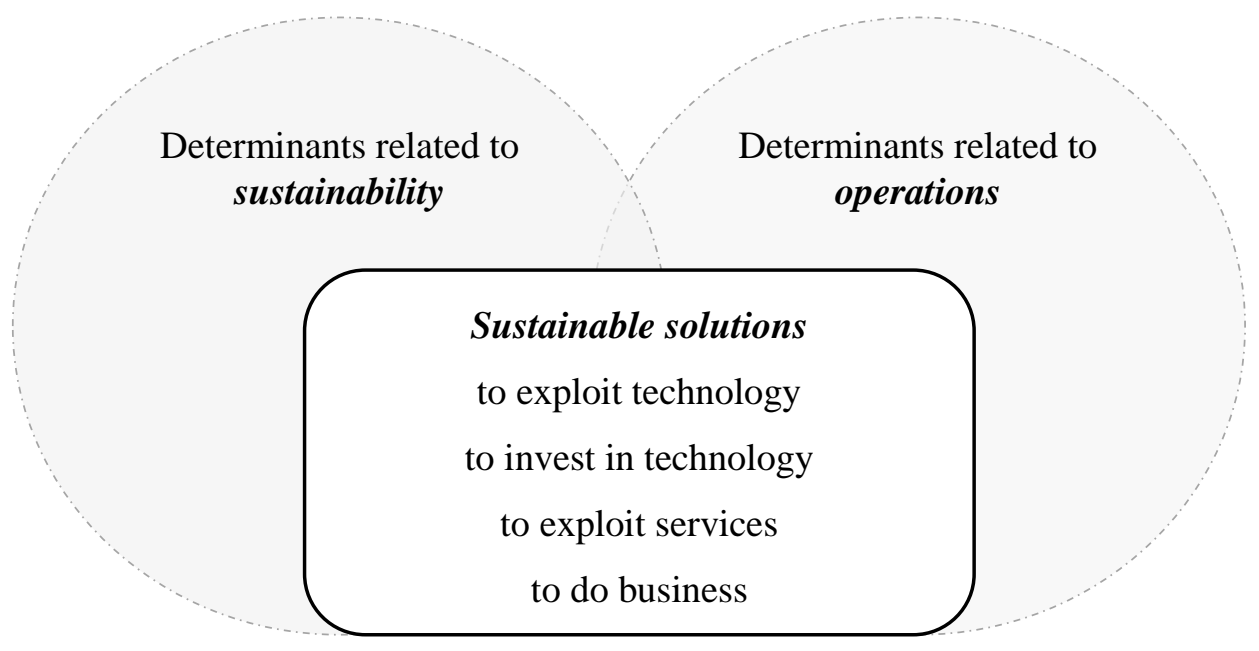

Figure 1. Research framework 


\section{Methodology}

\subsection{Sample and data collection}

The data for this study were gathered through an online survey questionnaire conducted in August and early September 2016. The population for this study comprised small Finnish companies operating in the horse industry. An invitation to participate in the survey was sent to 631 companies. Among the sent questionnaires, 580 reached the participants, and 51 came back to the researchers with return-to-sender messages, which indicated that the informants' email addresses were no longer valid. Two reminders were sent, after which the received data were screened. A total of 139 valid responses were received, equaling a response rate of around $24 \%$. To check the non-response bias, the respondents were divided into three groups: the first respondents, the first follow-ups, and the second follow-ups. Analysis of variance tests were run to check the non-response bias, and the analyses indicated that the responses reflected the entire sample well.

Table 1 presents the measurement instrument. The measures used in the survey included four items describing the horse industry operators' willingness to adopt sustainable solutions: to exploit technology, to invest in technology, to exploit services, and to do business. These sustainable solutions were identified from the literature and modified into items by the authors. Each item was measured on a scale of 1 to 7 , ranging from not at all willing to extremely willing. Fifteen items representing the different factors of sustainability were adopted from Delai and Takahashi (2011), Mamede and Gomes (2014), Svensson and Wagner (2015), and Khan et al. (2016). These variables were nutrient cycling, commitment to environmental causes, waste management, hygienic factors, energy consumption, land occupation, ease of material handling, social recognition, job creation, health and safety, human capital development, cost reduction, income, indirect jobs, and new business. For each item, the respondents were asked to indicate its significance on a scale of 1 to 7 .

Table 1. Measurement instrument

\begin{tabular}{|c|c|c|c|}
\hline & $\begin{array}{l}\text { Significance of } \\
\text { items }\end{array}$ & Items & Scale \\
\hline $\begin{array}{l}\text { Sustainability } \\
\text { determinants }\end{array}$ & $\begin{array}{l}\text { Indicates the } \\
\text { significance of the } \\
\text { items }\end{array}$ & $\begin{array}{l}\text { Nutrient cycling, commitment to } \\
\text { environmental causes, waste management, } \\
\text { hygienic factors, energy consumption, } \\
\text { land occupied, social recognition, job } \\
\text { creation, health and safety, human capital } \\
\text { development, cost reduction, income, } \\
\text { indirect job creation, new business, and } \\
\text { ease of material handling }\end{array}$ & $\begin{array}{l}1-7(1=\text { not at } \\
\text { all significant, } 7 \\
=\text { extremely } \\
\text { significant })\end{array}$ \\
\hline
\end{tabular}




\begin{tabular}{llll}
\hline $\begin{array}{l}\text { Operational } \\
\text { determinants }\end{array}$ & $\begin{array}{l}\text { Indicates the } \\
\text { significance of the } \\
\text { items }\end{array}$ & Perceived harms and perceived cost harms & $\begin{array}{l}1-7(1=\text { not at } \\
\text { all significant, 7 } \\
=\text { extremely } \\
\text { significant })\end{array}$ \\
\cline { 2 - 5 } & $\begin{array}{l}\text { Indicates the real } \\
\text { costs of manure } \\
\text { handling }\end{array}$ & Actual costs & $\begin{array}{l}\text { Amount in } \\
\text { euros }\end{array}$ \\
\hline $\begin{array}{l}\text { Sustainable } \\
\text { solutions }\end{array}$ & $\begin{array}{l}\text { Indicates } \\
\text { willingness to do } \\
\text { the items }\end{array}$ & $\begin{array}{l}\text { Technological exploitation, technological } \\
\text { investment, service, and business }\end{array}$ & $\begin{array}{l}1-7(1=\text { not at } \\
\text { all willing, } 7= \\
\text { extremely } \\
\text { willing })\end{array}$ \\
\hline
\end{tabular}

Two background variables (i.e., size and type of operation) were entered into the questionnaire. Three other variables, namely, perceived harms, perceived cost harms, and actual costs caused by manure handling, were also included to track the effects of such factors on the operators' willingness to adopt sustainable solutions. The significance of perceived harms and perceived cost harms was measured on a scale of 1 to 7 , from not significant to very significant. In terms of costs, the respondents were asked to provide the amount of costs in euros. The description of the data in terms of these variables is presented in Table 2.

Table 2. Description of data

\begin{tabular}{llcc}
\hline & & No & \% \\
\hline Size & Fewer than 20 horses & 68 & 48.9 \\
& $20-50$ horses & 62 & 44.6 \\
& Over 50 horses & 4 & 2.9 \\
& No answer & 5 & 3.6 \\
\hline Type of operation & Horserace & 26 & 18.7 \\
& Horse-riding & 98 & 70.5 \\
& Other & 13 & 9.4 \\
& No answer & 2 & 1.4 \\
\hline Perceived harms & No considerable harms & 93 & 66.9 \\
& Considerable harms & 45 & 32.4 \\
& No answer & 1 & 0.7 \\
\hline Perceived cost harms & No considerable cost harms & 78 & 56.1 \\
& Considerable cost harms & 58 & 41.7 \\
& No answer & 3 & 2.2 \\
\hline Actual costs & Less than 100 euros a month & 45 & 32.4 \\
& More than 100 euros a month & 72 & 51.8 \\
& No answer & 22 & 15.8 \\
\hline
\end{tabular}

\subsection{Results of the analyses}

The background variables (i.e., size, type of operation, and distance to a large industry operator) did not affect at a statistically significant level how willing the company is to exploit 
technology, to invest in technology, to exploit services, or to conduct business. Next, whether differences could be found among companies with different amounts of perceived harms, perceived cost harms, and actual costs caused by the handling of horse manure was investigated.

First, the differences were studied according to the amount of perceived harms. The sample was divided into those that considered horse manure handling as considerable harm (mean 5 and higher) and those who did not (mean less than 5). As indicated in Table 3, a significant difference was found in all four items. Thus, the amount of perceived harms that horse manure brings to the company affects how willing the company is to exploit technology, to invest in technology, to exploit services, and to conduct business.

Second, the differences were studied according to the amount of perceived cost harms. The sample was divided into those that considered horse manure handling as a considerable cost harm (mean 5 and higher) and those that did not (mean less than 5). The results in Table 3 indicate significant differences in all four items. Therefore, the amount of perceived cost harms that horse manure brings to the company affects how willing the company is to exploit technology, to invest in technology, to exploit services, and to conduct business.

Third, the differences between actual costs were studied. The sample was divided into the companies with costs of less than 100 euros a month in handling horse manure and those with costs of more than 100 euros a month. The results in Table 3 indicate significant differences between the two items. Thus, the amount of costs that horse manure brings to the company affects how willing the company is to exploit and invest in technology but not how willing it is to exploit services or to conduct business.

Table 3. Differences in willingness to exploit sustainable solutions based on operational determinants

\begin{tabular}{|c|c|c|c|c|}
\hline \multirow[t]{3}{*}{ Sustainable solutions } & \multicolumn{3}{|l|}{ Means } & \multirow[t]{3}{*}{ Difference } \\
\hline & Perceived & harms & & \\
\hline & Low & High & Z-score & \\
\hline Willingness to exploit technology & 4,4889 & 6,1364 & $-4,297 * * *$ & Significant difference \\
\hline Willingness to invest in technology & 3,1573 & 4,7955 & $-4,300 * * *$ & Significant difference \\
\hline Willingness to exploit services & 4,5000 & 5,9333 & $-3,571 * * *$ & Significant difference \\
\hline \multirow[t]{3}{*}{ Willingness to conduct business } & 4,1222 & 5,2955 & $-2,992 * *$ & Significant difference \\
\hline & Perceived & cost ha & & \\
\hline & Low & High & & \\
\hline Willingness to exploit technology & 4,2105 & 6,1607 & $-5,368 * * *$ & Significant difference \\
\hline Willingness to invest in technology & 2,9467 & 4,6071 & $-4,654 * * *$ & Significant difference \\
\hline Willingness to exploit services & 4,3117 & 5,8448 & $-3,709 * * *$ & Significant difference \\
\hline \multirow[t]{2}{*}{ Willingness to conduct business } & 3,9733 & 5,1404 & $-3,118 * *$ & Significant difference \\
\hline & Actual & costs & & \\
\hline
\end{tabular}




\begin{tabular}{l|lll|l}
\cline { 5 - 5 } & Low & High & \\
\hline Willingness to exploit technology & 4,2727 & 5,7246 & $-3,600^{* * *}$ & Significant difference \\
Willingness to invest in technology & 2,6818 & 4,4559 & $-4,451^{* * *}$ & Significant difference \\
Willingness to exploit services & 4,6364 & 5,5556 & $-2,002$ & Not significant difference \\
Willingness to conduct business & 4,2000 & 4,8088 & $-1,505$ & Not significant difference \\
\hline \multicolumn{5}{c}{ Sign. ${ }^{* * *} \mathrm{p} \leq 0.001,{ }^{* *} 0.001<\mathrm{p} \leq 0.01$}
\end{tabular}

Figure 2 illustrates the differences among companies with high perceived harms, perceived cost harms, and actual costs from horse manure handling. When perceived harms and perceived cost harms were high, willingness to adopt sustainable solutions was high. When actual costs were high, willingness to adopt sustainable solutions was not as high.

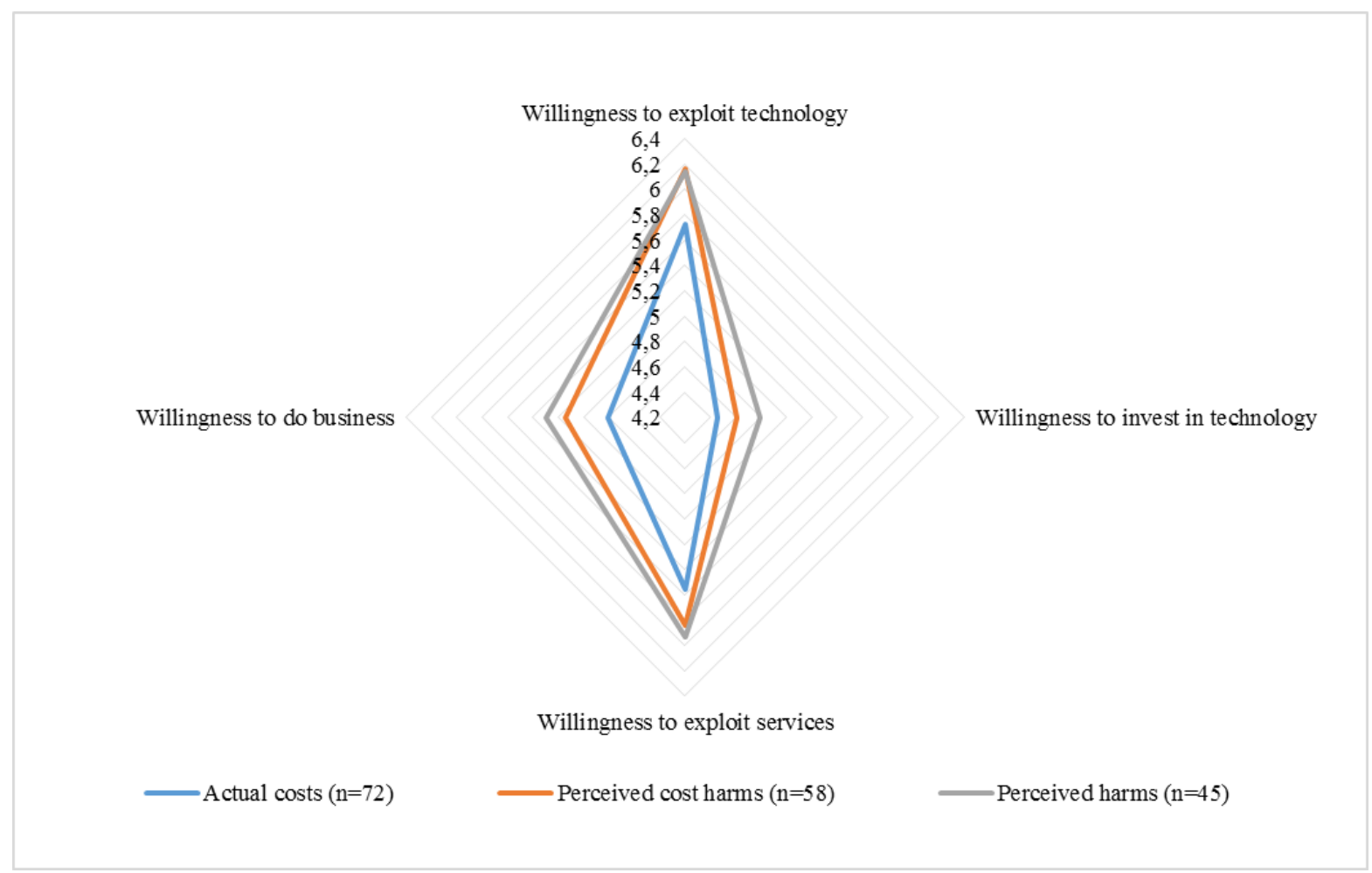

Figure 2. Willingness to adopt sustainable solutions among the companies that consider operational determinants to be significant

Next, the data were divided into companies that are willing to adopt sustainable solutions (exploit technology, invest in technology, exploit services, or conduct business) (mean 5 and higher) and those that are not (mean less than 5). The means of the companies willing to adopt sustainable solutions were analyzed. Figure 3 illustrates the description of the data by means. It presents what aspects of sustainability are valued by the companies that are most willing to utilize different sustainable solutions. The results show that these companies value ease of material handling, reduction of energy consumption, and cost reduction. Social recognition, human capital development, and job creation are also important for companies that are willing to exploit or invest in sustainable technologies. 


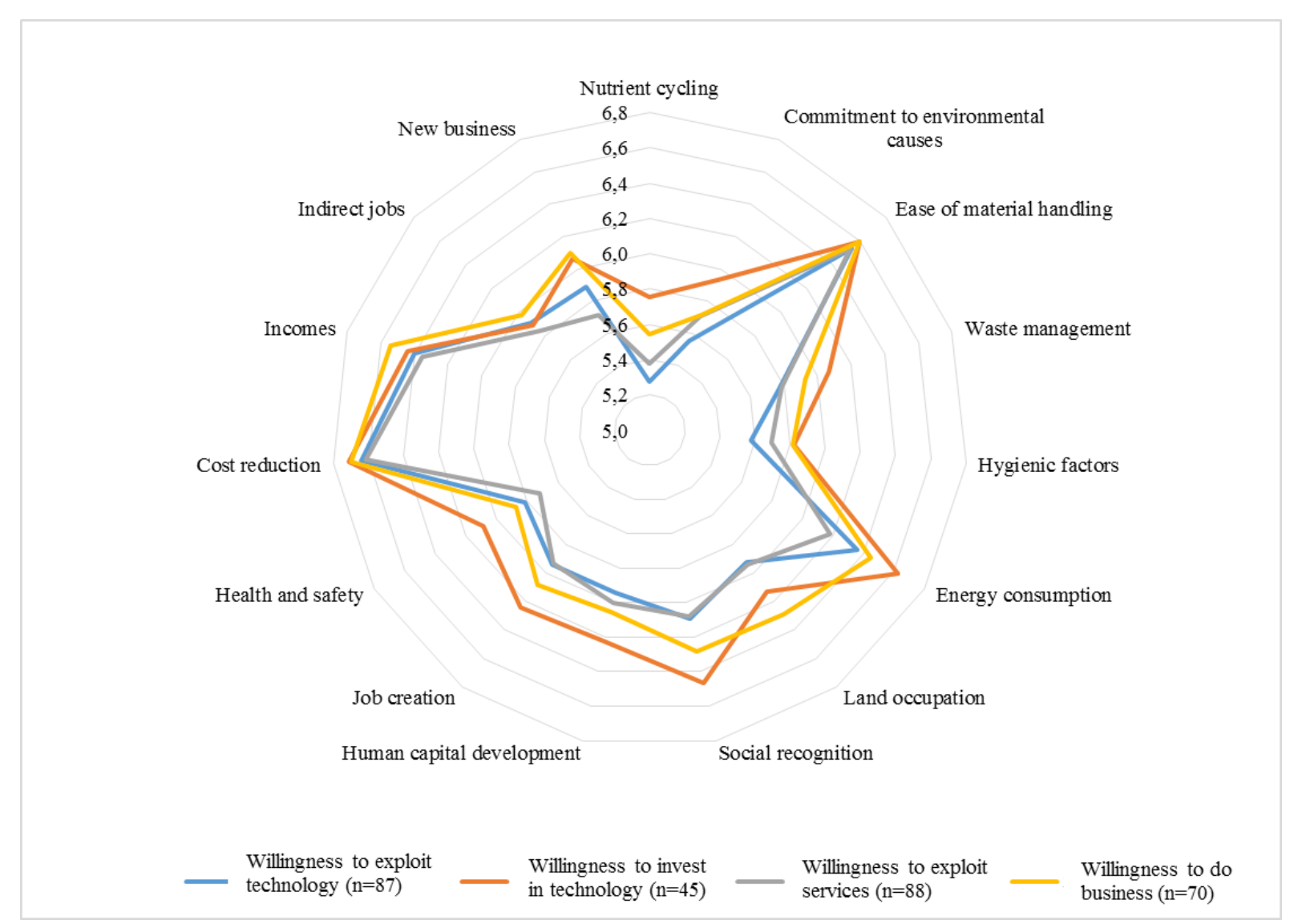

Figure 3. Sustainability determinants of the companies willing to adopt sustainable solutions

\section{Discussion}

This study examines the determinants of the adoption of sustainable solutions in the horse industry. Previous studies have recently presented cost savings and stricter regulations to be the most frequently proposed determinants of eco-innovation (e.g., Kesidou and Demirel, 2012; Horbach et al., 2012; Horbach et al., 2013; Del Río et al., 2015; Hojnik and Ruzzier, 2016). Although Hojnik and Ruzzier (2016) presented that many external efforts, such as governmental regulations and increased customer awareness, have been directed toward motivating companies to adopt sustainable solutions in terms of eco-innovation, the results of this study do not fully support this. The findings of this study show that among horse industry operators, the most important sustainability determinants that increase their willingness to adopt and utilize sustainable solutions are related to the ease of solutions, energy consumption, and cost reduction. To promote the ease of adopted and utilized solutions, the adoption of sustainable services is considered to be an attractive option. The utilization of sustainable services to solve the horse industry's current problems related to manure handling is an example of a result-oriented service (Laperce and Picard, 2013), in which the service provider has responsibility for all the costs of delivering results and thus strong incentive for manure and energy use. In general, the results of this study indicate that increased internal efficiency and facilitation of operators' operating activities is the most important motivator for the adoption of sustainable solutions. 
In addition to cost saving and external pressures, environmental commitment is considered one of the motivators for the adoption of sustainable solutions (Chen et al., 2006). Although the results of the Sáez-Martínez et al. (2014) revealed that in the contemporary business environment, companies have a greater awareness of the influence of their activities on the environment and are increasingly motivated by environmental concerns in their pursuit of new solutions and innovations, the results of this study reveal that greater awareness does not directly determine the adoption of sustainable solutions among horse industry operators. The results of the study are in accordance with the findings of previous studies (e.g., Horbach et al., 2012; Horbach et al., 2013; Del Río et al., 2015; Hojnik and Ruzzier, 2016), which argue that cost savings and cost reduction are some of the most meaningful factors that determine the adoption and utilization of sustainable solutions aside from ease of the adopted and utilized solutions. Based on the evidence from this study, this situation also seems to be the case in the horse industry. However, the greater awareness of environmental concerns and environmental commitment along with the current cost reduction can be linked to energy consumption, which is one of the most important factors determining the current utilization and adaption of sustainable solutions in the horse industry.

The study findings also reveal that among operational determinants, horse industry operators with high manure-handling costs are willing to exploit and invest in technology. This result may indicate that technology-based solutions are considered to have a higher potential in cost reduction compared with service-based and business-related solutions. This perception can also be supported by the reluctance of operators with low cost to make technological investments. Therefore, the findings indicate that related to operational determinants, perceived cost harms increase the willingness of horse industry operators to utilize and adopt different sustainable solutions (i.e., technological, service, and business-related solutions), but the actual high-level costs shift their willingness to conduct technology utilization and investment. Currently, sustainable technology utilization and investment are considered the most important solutions to reduce the operational cost caused by manure handling.

Although energy consumption and cost reduction seem to be the main determinants for the exploitation of sustainable solutions, the willingness to invest in technologies seems to be associated with social sustainability in terms of social recognition, human capital development, and job creation (Figure 1). These results are in accordance with McKinsey's global survey on the business of sustainability, which summarizes that companies consider effects on reputation as one of expected benefits of sustainability. Moreover, Sousa-Zomer and Cauchick Miguel (2016) conclude that business model innovations with a social component enable a close interaction with other stakeholders and help to change their unsustainable behavior. They find that business models focusing on the delivery of environmental and social benefits rather than economic profit alone can lower environmental costs (e.g., lower energy consumption). This finding may indicate that horse industry operators investing in technologies can also be 
considered pioneers in the industry and interested in adopting business model innovations as well.

\section{Conclusions}

This study investigates the determinants of the adoption of sustainable solutions in the horse industry. The determinants are divided into those related to sustainability and operations. The results show that the most important determinants are related to operators' motivation to improve their internal efficiency and operating activities. The most important sustainability determinants were ease of the solutions, energy consumption, and cost reduction. Among operational determinants, the perceived cost harms seem to increase the horse industry operators' willingness to adopt different types of sustainable solutions. Although the perceived cost harms seem to increase the operators' motivation to develop sustainable solutions, the actual costs shift the focus of sustainable solutions toward technological solutions. This finding indicates that compared with service and business-related solutions, technologically related sustainable solutions are perceived to be most attractive in cost cutting and cost reduction.

Regarding managerial implications, this study deepens understanding of the influence of sustainability and operations determinants on the adoption of sustainable solutions. The study results indicate that the motivations for adopting sustainable solutions are more internal than external. When developing more sustainable policies and solutions to agriculture-related industries, government decision makers and politicians should be aware of the determinants driving operators to adopt and utilize sustainable solutions. The study results, therefore, can increase understanding of the development of sustainable solutions in agriculture-related industries. Instead of more regulations and laws, it seems that policymakers should direct their interest to supporting horse industry operators' internal motivations to adopt sustainable solutions. Along with decision makers, sustainable solution developers and providers, such as service and technology providers, should be aware of the determinants motivating horse industry operators to adopt sustainable solutions.

Although the results of this study indicate that the internal motivation and facilitation of internal activities seem to be a meaningful reason for horse industry operators to adopt sustainable solutions, the phenomenon needs more evidence. Therefore, future research could explore in more detail the differences between the internal and external determinants of sustainable solutions in the horse industry. Note that the results were gathered from one country and in one agriculture-related industry. Therefore, the generalization of the results should be done judiciously even if national differences, even differences in the horse industry, have become less important. 


\section{References}

Almeida, C.M.V.B., Bonilla, S.H., Giannetti, B.F. \& Huisingh, D. (2013). Cleaner Production initiatives and challenges for a sustainable world: An introduction to this special volume. Journal of Cleaner Production, 47, 1-10.

Anadon, L.D., Chan, G., Hurley, A., Matus, K., Moon, S., Murthy, S. \& Clark, W.C. (2015). Making technological innovation work for sustainable development. Harvard Kennedy School $\begin{array}{lllll}\text { Research } & \text { Working } & \text { Paper }\end{array}$ https://research.hks.harvard.edu/publications/workingpapers/Index.aspx

Arnold, M. (2017). Fostering sustainability by linking co-creation and relationship management concepts. Journal of Cleaner Production, 140, 179-188.

Bar, E.S., 2015. A case study of obstacles and enablers for green innovation within the fish processing equipment industry. Journal of Cleaner Production, 90, 234-243.

Björkdahl, J. \& Holmén, M.. (2013). Editorial: Business model innovation-The challenges ahead. International Journal of Product Development, 18 (3), 213-225.

Bocken, N.M.P., Short, S.W., Rana, P. \& Evans, S. (2014). A literature and practice review to develop sustainable business model archetypes. Journal of Cleaner Production, 65, 42-56.

Bolton, R. \& Hannon, M. (2016). Governing sustainability transitions through business model innovation: Towards a systems understanding. Research Policy, 45 (9), 1731-1742.

Bonini, S. \&Görner, S. (2011). The business of sustainability: McKinsey Global Survey results. At: $\quad$ http://www.mckinsey.com/business-functions/sustainability-and-resourceproductivity/our-insights/the-business-of-sustainability-mckinsey-global-survey-results

Boons, F., \& Lüdeke-Freund, F. (2013). Business models for sustainable innovation: State-ofthe-art and steps towards a research agenda. Journal of Cleaner Production, 45, 9-19.

Bossle, M. B., de Barcellos, M. D., Vieira, L. M., Sauvée, L. (2016). The drivers for adoption of eco-innovation. Journal of Cleaner Production, 113, 861-872.

Brundtland, G., Khalid, M., Agnelli, S., Al-Athel, S., Chidzero, B., Fadika, L., Hauff, V., Lang, I., Shijun, M., de Botero, M., Singh, M., Okita, S., Others, (1987). Our Common Future ('Brundtland report'), Oxford Paperback Reference. Oxford University Press, USA.

Cai, W.G., \& Zhou, X.L. (2014). On the drivers of eco-innovation: empirical evidence from China. Journal of Cleaner Production, 79, 239-248. 
Calabi-Floody, M., Medina, J., Rumpel, C., Condron, L.M., Hernandez, M., Dumont, M., \& de la Luz Mora, M. (2018). Chapter three - Smart fertilizers as a strategy for sustainable agriculture. Advances in Agronomy, 147, 119-157.

Calabrese, A., Castaldi, C., Forte, G., \& Levialdi, N.G. (2018). Sustainability-oriented service innovation: An emerging research field. Journal of Cleaner Production, 193, 533-548.

Chang, C.H. (2016). The determinants of green product innovation performance. Corporate Social Responsibility and Environmental Management, 23, 65-76.

Chang, C.H., \& Chen, Y.S. (2013). Green organizational identity and green innovation. Management Decision, 51 (5), 1056-1070.

Chassagnon, V. \& Haned, N. (2015). The relevance of innovation leadership for environmental benefits: A firm-level empirical analysis on French firms. Technological Forecasting and Social Change, 91, 194-207.

Chen, Y.S., Lai, S.B., \& Wen, C.T. (2006). The influence of green innovation performance on corporate advantage in Taiwan. Journal of Business Ethics, 67 (4), 331-339.

Chesbrough, H. (2010). Business model innovation: Opportunities and barriers. Long Range Planning, 43, 354-363.

Choi, S., \& Ng, A. (2011). Environmental and economic dimensions of sustainability and price effects on consumer responses. Journal of Business Ethics, 104 (2), 269-282.

Del Río, P., Romero-Jordán, D., \& Peñasco, C. (2015). Analysing firm-specific and typespecific determinants of eco-innovation. Technological and Economic Development of Economy, 1-26.

Delai, I. \& Takahashi, S. (2011). Sustainability measurement system: A reference model proposal. Social Responsibility Journal, 7 (3), 438-471.

Diaz Lopez, F.J., Bastein ,T., \& Tukker, A. (2018). Business model innovation for resourceefficiency, circularity and cleaner production: What 143 cases tell us. Ecological Economics https://doi.org/10.1016/j.ecolecon.2018.03.009

Doran, J., \& Ryan, G. (2012). Regulation and firm perception, eco-innovation and firm performance. European Journal of Innovation Management, 15 (4), 421-441. 
Enquist, B., Petros Sebhatu, S., \& Johnson, M. (2015). Transcendence for business logics in value networks for sustainable service business. Journal of Service Theory and Practice, 25 (2), 181-197.

Furrer, O. (2010). A customer relationship typology of product services strategies. In: Gallouj, D. (Ed.), The handbook of innovation and services. Edward Elgar Publishing

Galdeano-Gómez, E., Aznar-Sánchez, J.A., \& Pérez-Mesa, J.C. (2013). Sustainability dimensions related to agricultural-based development: the experience of 50 years of intensive farming in Almería (Spain). International Journal of Agricultural Sustainability, 11 (2), 125143.

Gao, Y., Li, P., Wu, L., Lu, J., Yu, L., \& Yin, S. (2018). Support policy preferences of forprofit pest control firms in China. Journal of Cleaner Production, 181, 809-818.

Geum, Y.\& Park, Y. (2011). Designing the sustainable product-service integration: A productservice blueprint approach. Journal of Cleaner Production, 19 (14), 1601-1614.

Girotra, K. \& Netessine, S. (2013). OM forum-Business model innovation for sustainability. Manufacturing \& Service Operations Management. 15 (4), 537-544.

Goodland, R. \& Daly, H. (1996). Environmental sustainability: universal and non-negotiable. Ecological Applications, 6 (4), 1002-1017.

Hacatoglu, K., Rosen, M.A. \& Dincer, I. (2013). An Approach to Assessment of Sustainability of Energy Systems. In: Dincer, I., Colpan, C.O and Kadioglu, F. (Ed.), Causes, impacts and solutions to global warming, 363-387. Springer.

Hojnik, J., \& Ruzzier, M. (2016). What drives eco-innovation? A review of an emerging literature. Environmental Innovation and Societal Transitions, 19, 31-41.

Horbach, J., Rammer, C., \& Rennings, K. (2012). Determinants of eco-innovations by type of environmental impact-The role of regulatory push/pull, technology push and market pull. Ecological economics, 78, 112-122.

Horbach, J., Oltra, V., \& Belin, J. (2013). Determinants and specificities of eco-innovations compared to other innovations - an econometric analysis for the French and German industry based on the community innovation survey. Industry and Innovation, 20 (6), 523-543. 
Huang, X.X., Hu, Z.P., Liu, C.S., Yu, D.J., \& Yu, L.F. (2016). The relationships between regulatory and customer pressure, green organizational responses, and green innovation performance. Journal of Cleaner Production, 112, 3423-3433.

Huesemann, M. (2003). The limits of technological solutions to sustainable development. Clean Technologies and Environmental Policy, 5 (1), 21-34.

Kesidou, E., \& Demirel, P. (2012). On the drivers of eco-innovations: Empirical evidence from the UK. Research Policy, 41 (5), 862-870.

Khan, E.A., Dewan, M.N.A. \& Chowdhury, M.H. (2016). Reflective or formative measurement model of sustainability factor: A three industry comparison. Corporate Ownership and Control Journal, 12 (2), 84-94.

Laperche, B. \& Picard, F. (2013) Environmental constraints, Product-Service Systems development and impacts on innovation management: learning from manufacturing firms in the French context, Journal of Cleaner Production, 53, 118-128.

Liljenstolpe, C. (2009). Horses in Europe. EU Equus. Retrieved at http://www.wbfsh.org/files/EU\%20Equus\%202009.pdf.

Long, T.B., Blok, V. \& Coninx, I. (2016). Barriers to the adoption and diffusion of technological innovations for climate-smart agriculture in Europe: Evidence from the Netherlands, France, Switzerland, and Italy. Journal of Cleaner Production, 112, 9-21.

Lovins, A.B., Lovins, L.H. \& Hawken, P. (1999). A road map for natural capitalism. Harvard Business Review (1999), 1-14.

Lovins, A.B., Lovins, L.H. \& Hawken, P. (2007). A road map for natural capitalism. Harvard Business Review.

Lozano, R., Lukman, R., Lozano, F.J., Huisingh, D. \& Lambrechts, W. (2013). Declarations for sustainability in higher education: Becoming better leaders, through addressing the university system. Journal of Cleaner Production, 48, 10-19.

Lozano, R., 2015. A Holistic perspective on corporate sustainability drivers. Corporate Social Responsibility and Environmental Management, 22, 32-44.

Lüdeke-Freund, F. (2010). Towards a conceptual framework of business models for sustainability. Environmental Management, 49, 1-28. 
Lüdeke-Freund, F., \& Dembek, K. (2017). Sustainable business model research and practice: emerging field or passing fancy? Journal of Cleaner Production, 168, 1668-1678.

Mamede, P. \& Gomes, C.F. (2014). Corporate sustainability measurement in service organizations: A case study from Portugal. Environmental Quality Management, 23 (3), 4973.

Martin, D., Gustafsson, A. \& Choi, S. (2016). Service innovation, renewal, and adoption/rejection in dynamic global contexts. Journal of Business Research, 69 (7), 23972400 .

Moldan, B., Janoušková, S. \& Hák, T. (2012). How to understand and measure environmental sustainability: Indicators and targets. Ecological Indicators, 17, 4-13.

Morelli, J., (2011). Environmental sustainability: A definition for environmental professionals. Journal of Environmental Sustainability, 1 (1), 1-27.

Munasinghe, M. \& Cutler, J. (2004). Sustainable development: basic concepts and application to energy. Encyclopedia of Energy 5, 789-808.

Pfahl, S., 2005. Institutional sustainability. International journal of sustainable development, 8 (1-2), 80-96.

Pretty, J., Toulmin, C., \& Williams, S. (2011). Sustainable intensification in African agriculture. International Journal of Agricultural Sustainability, 9 (1), 5-24.

Qi, G.Y., Shen, L.Y., Zeng, S.X., \& Jorge, O.J. (2010). The drivers for contractors' green innovation: an industry perspective. Journal of Cleaner Production, 18 (14), 1358-1365.

Radulescu, C.V. (2017). Sustainability Strategies in Businesses. Quality - access to success, 17, 331-336.

Sáez-Martínez, F. J., Díaz-García, C., \& González-Moreno, A. (2014). Environmental orientation as a determinant of innovation performance in Young SMEs. International Journal of Environmental Research, 8 (3), 635-642.

Schaltegger, S., Lüdeke-Freund, F. \& Hansen, E. (2012). Business cases for sustainability and the role of business model innovation. International Journal of Innovation and Sustainable Development, 6 (2), 95-119.

Scherr, S., Shames, S. \& Friedman, R. (2012). From climate-smart agriculture to climate-smart landscapes Agriculture \& Food Security, 1 (12), 1-15. 
Shrivastava, P., Ivanaj, S \& Ivanaj, P., 2016. Strategic technological innovation for sustainable development. International Journal of Technology Management, 70 (1), 76-107.

Snyder, H., Witell, L., Gustafsson, A., Fombelle, P. \& Kristensson, P. (2016). Identifying categories of service innovation: A review and synthesis of the literature. Journal of Business Research, 69 (7), 2401-2408.

Sousa-Zomer, T.T. \& Cauchick Miguel, P.A. (2016). Sustainable business models as an innovation strategy in the water sector: An empirical investigation of a sustainable productservice system, Journal of Cleaner Production. (in Press)

Svensson, G. \& Wagner, B. (2015). Implementing and managing economic, social and environmental efforts of business sustainability. Management of Environmental Quality: An International Journal, 26 (2), 195-213.

Vollebergh H. \& Kemfert C. (2005). The role of technological change for a sustainable development. Ecological Economics, 54, 133-147.

Wamsler, C., \& Brink, E. (2018). Mindsets for sustainability: Exploring the link between mindfulness and sustainable climate adaption. Ecological Economics, 151, 55-61.

Weddu, Y. \& Assefa, G. (2017). The search for most cost-effective way of achieving environmental sustainability status in electricity generation: Environmental life cycle cost analysis of energy scenarios. Journal of Cleaner Production, 142, 2296-2304

Yang, M., Evans, S., Vladimirova, D. \& Rana, P. (2016). Value uncaptured for sustainable business model. Journal of Cleaner Production, 140, 1794-1804.

Zailani, S., Govindan, K., Iranmanesh, M., Shaharudin, M.R., Chong, Y.S. (2015). Green innovation adoption in automotive supply chain: the Malaysian case. Journal of Cleaner Production, 108, 1115-1122. 